\title{
Of Form, Closed and Open: with Glances at Frost and Williams - Richard Moore
}

THE QUESTION KEEPS haunting us. Have we done well, virtually to banish rhyme and meter from our poetry? What matters, of course, is what, if anything, they can actually do for the effect of a poem. There may have been a time in dim troubadour antiquity when such formalities could boast an independent significance - as when terza rima seems directly to saturate Dante's Commedia with the presence of the Holy Trinity-but such naive civilities, we will want to agree, I think, are not for us of the twentieth century. Our sensibilities require something more functional to a poem's actual or imagined performance: something more earthly, more utilitarian.

But I don't think we are going to get very far in rating the effect of explicit sound patterns in verse until we compare the effect of their absence-or rather, the effect of their blurring and loosening, since we will never get rhythm out of speech altogether. Already, incidentally, in this very need for such a comparison, I think we have stumbled on a reason for free verse which is more fundamental, more satisfying than Pound's or Williams' struggle against gentility. Rhyme seems to have come from nowhere in the Middle Ages, in a generation or two displacing Germanic alliteration and Celtic assonance and taking over the Latin hymns. It seems to have come from the Saracen regions: in the atmosphere of the Crusades probably a difficult origin to acknowledge. Unlike the meters of ancient Greek, therefore, the laws of our verse did not have the naturalness that immemorial usage could give. They did not seem to arise from within the language but were clearly imposed from without. Like our religion earlier and our science later, our verse was dogmatic and artificial from its beginning. Seen in this way, free verse was as inevitable as existentialism. Only doubt, finally, can affirm dogma. The nagging sense of artificiality gave us the need to understand what rhyme and meter actually did for us, a question we could answer only by trying - and learning - to do without them. Give a child a cup with the announcement that it is unbreakable, and sooner or later he will have a go at smashing it, first casually, then, if he fails, as a slowly deepening obsession. For the Greeks and Romans, the 
gift of formal verse was more like a monkey wrench. Its function and strength were so self-evident that no one ever even thought of trying to break it. So it just slowly got rusty over the centuries until finally it became unusable.

No poet in English made more of an issue of hewing to the line in metrical matters than Robert Frost-

\title{
PERTINAX
}

\author{
Let chaos storm! \\ Let cloud shapes swarm! \\ I wait for form.
}

Is there a comic smugness in this? In that second line do the virtually unpronounceable consonant combinations and the spondee threaten to burst the form, giving a touch of drama to the whole? I shall consider a sample or two of Frost's work, and then - who is Frost's metrical antithesis? Not Pound surely, who had considerable sympathy for Frost's program and wrote sonnets himself. No, the pure negation of Frost's traditional metric is in the work of William Carlos Williams, who, as far as I know, never published a rhyme and never let one iamb follow another if he could possibly help it. It was Williams more than any other poet of that pioneering generation who faced up boldly, if not always rationally, to the problem of creating a verse which neither uses nor alludes to any conventional, externally imposed metric; and it is for this reason that he, more than anyone else - and justly so - is virtually the patron saint of contemporary American poetry. Open any issue of almost any of the vast number of literary magazines being published constantly in English and there will be Williams poems everywhere, and to the exclusion of all other kinds: poems with his total innocence of rhyme and meter, his casual familiarity of tone, his broken sentences, his heavy reliance on imagery, even many of his social attitudes, but - as always when there is a multitude of followers very little of his art.

Yet the opposition between Frost and Williams may not be as total as it sometimes seems. Frost's resistance to free verse and Williams' condemnation of meter have a similar quality: an extremism, a defensiveness. Both were responding to the same perceived crisis in English prosody: a nag- 
ging sense that the iambic TI-TUM TI-TUM might have outlived its usefulness. It had been harped on and appropriated by too many maiden aunts and sentimental grandmothers. After all, hadn't tonality in music and perspective in painting worn themselves out by the end of the first decade of the Century and for similar reasons: that they had become the media for all the lies we had begun to tell each other about ourselves? What delicious ferment in those times! What wonderful possibilities: to throw out the old and invent new media and start telling the truth forthwith! But can we invent new media? Is it possible? Can we, for example, invent an actual language? That too was tried. But what has become of Esperanto? Hopetalk!

But - the inventors reply - if you have inherited a dead language and if you propose to say anything, you will have to invent a language in any case. This is true; and I think Frost was aware of it. I think that one of the secrets of his power as a poet is that he alludes to the deadness of his language and of his verse forms constantly. Instead of trying to throw them out, as did Williams, he fondles them, he plays with them. He is deeply aware of his predicament - like an old lover who has lost his illusions but who knows that separation, for him at least, is impossible. Take the last line of that little poem I just quoted, "I wait for form." If the pure, the quintessential TI-TUM has ever occurred, it surely has there. That is why it is smug-and comic. It cannot be otherwise after the mock heroism leading up to it. "Let chaos storm!" It is the primary Romantic Gesture: Beethoven on his deathbed, shaking his fist at the thunder and lightning. But the self-contained fellow in this poem is going to ignore all that grandeur and wait for his little ticktock. Surely there is the implication in all this that form may, after all, be nothing much to wait for. But that, in turn, may be like the "nothing much" in Zen Buddhism: it may be everything. We are beginning to learn that Frost was a poet of endlessly delicate ironies.

But let us look at a more considerable example:

\section{RANGE-FINDING}

The battle rent a cobweb diamond-strung

And cut a flower beside a ground bird's nest

Before it stained a single human breast. 
The stricken flower bent double and so hung. And still the bird revisited her young.

A butterfly its fall had dispossessed

A moment sought in air his flower of rest,

Then lightly stooped to it and fluttering clung.

On the bare upland pasture there had spread

O'ernight 'twixt mullein stalks a wheel of thread

And straining cables wet with silver dew.

A sudden passing bullet shook it dry.

The indwelling spider ran to greet the fly,

But finding nothing, sullenly withdrew.

This has seemed a magnificent poem to me since the moment I encountered it in Frost's Complete Poems twenty or thirty years ago, but since then I have seen it in only one anthology-quite recently. That spider with its horrible greeting at the end and the overall implication that war is as natural as anything else in nature-Romantic Nature! - may account for this poem having been discreetly passed over by many a wary anthologist. To make an anthology, after all, is a public, a political act ... and Frost's political attitudes-including, among other embarrassments, his belief that war is a normal and desirable human expression - may have cost him many things. (The Nobel Prize springs to mind.)

But the poem, surely, is inspired the way it builds up its effects. It seems to start out to say that war is as inimical and destructive to the life in nature as it is to man himself. The well-worn cliché, that war is unnatural, a principle absolutely opposed to the principle of life, seems to be waiting in the wings, ready to make a triumphal entry. The "cobweb diamondstrung," the flower, and the bird's nest impinge on us first as standard images of nature's benign loveliness, and the vague, tired language of the line, "Before it stained a single human breast," places the human reality at a convenient distance. Clearly in this three-line opening, the poet is playing with the deadness of his medium: in perfectly regular iambic we have a commonplace idea, conventional nature symbols, and an even more conventional line about man himself.

Then without warning comes the terribly immediate, "The stricken flower bent double and so hung." There is the anthropomorphic "bent double"-the way a man would respond to a bullet in the gut-but the 
main effect is in the rhythm: the uncertainity about whether "flower" has one or two syllables (it has to have one here) and the violent spondeepyrrhic-spondee which ends the line. Man has been forgotten and the poem is now caught up in its microcosm. The range has been found.

The meter returns to normal for the bird returning to her young, and we hardly notice this first reversal of motion in the theme: in some respects, apparently, life is going to go on undisturbed, at least for the moment-a microcosm of time to correspond to the microcosm of space. The reaction of the butterfly is similar: it misses its "flower of rest" only for a moment. At the end of the octave all has settled nonchalantly back to normal after the first bullet. And something else has happened as well: the poem with its elegance of form and evident relish in detail is leading us to a strangely detached and esthetic attitude toward the whole scene. It is something like the clinical, almost loving detail that one finds in the endless battle scenes of the Iliad: an estheticism about death itself. Idomeneus thrusts his spear into his opponent's chest and feels the man's expiring heartbeats faintly vibrating in his spearshaft. I'm sure that Frost took a Homeric delight in the "its" in line 6 . The grammar is all very correct, of course. "Its" can't refer to "the bird" in line 5 because the bird has already been referred to as a "her"; so "its" must refer to "flower" in line 4. But this, though correct, is confusing, and we remain in suspense until the repetition of "flower" in line 7. Isn't this an awkwardness, then-a fatal flaw in the Petrarchan elegance, proving-as Williams announced and Eliot suggested - that the sonnet is indeed a dead form? On the contrary. This may be the most elegant turn in the whole poem; for our uncertainty about the reference of the pronoun reflects - and makes us feel in our experience of the syntax - the butterfly's uncertainty about the missing flower. Form and content are one. After this, it is almost anticlimactic to observe that the concluding words of the octave, "to it and fluttering clung," are a rhythmic marvel, not just in themselves, but because we have to think of them as three iambs. The established iambic pattern clearly measures and thereby emphasizes the impression of delicate fragility created by the hesitant pyrrhic and the near-anapest.

The sestet very gracefully and elegantly both repeats the octave and carries it forward to the poem's devastating conclusion. The rent cobweb and cut flower have been mentioned and the cut flower described; so now, in parallel, the rent cobweb has to be described. But the microscopic scale has 
been so firmly established that the cobweb can now be presented in almost epic grandeur as some kind of vast engineering project, famous for its beauty, like, say, the Golden Gate bridge: "a wheel of thread / And straining cables wet with silver dew." The grand sweep of these phrases, spilling over the line endings and carrying the metric units with them, stands in vivid contrast to the next line, which punctures the glittering illusion: "A sudden passing bullet shook it dry." What a brilliant bit of observation - and what an inspired rhythmic shift! That crudely trochaic bullet does so much-and yet so little. The devastation is all in our suddenly changed point of view: man has entered. But his unnatural destructiveness? Even so frail a thing as a cobweb is left substantially intact. "The indwelling spider ran ..." In terror for his life? To do battle with the monster who was tearing his web to pieces? At the moment I feel inclined to nominate the actual ending of this line, "to greet the fly," as the most diabolical phrase in English Literature. We have been looking at the situation from our point of view, unmindful of the fact that the spider is going to look at it from his. What a superbly counterpointed perception this induces in us! We see that the bullet was not momentous at all to the spider-but the spider sees that it was momentous. It made him think his dinner was ready. In the octave we had seen the sweet, friendly, loving side of nature - the bird that tends her young, the flower that like a fallen hero even in death serves its beloved butterfly, the butterfly that shall not search in vain-and now, as an echo of that friendliness, we have this word "greet." (In some earlier version of the poem was it "eat"?) An uglier word than the one we have could scarcely be imagined. Suddenly the poem has turned inside out on us, revealing what was there in it potentially from the beginning: man can add no cruelty to nature that is not to be found there already.

And yet-is that all? In the light of what we might have been hoping for (some consolation, some belief that somewhere, if not in man, then in nature perhaps, there is order, goodness) the last line of the poem comes as a cruel dismissal. The spider finds nothing and goes back to his hiding place "sullenly" - the first unmistakably human word in this microcosm: we have returned to the world of men. And in so doing, we are reminded of the irony of the spider "finding nothing." There would be a whole world for him to find if he were not a spider. There is a human point of view, after all, and the spider is, indeed, very human. He makes me think 
of the anthologists who must have read this poem, felt vaguely uncomfortable, found nothing, and sullenly withdrawn from it. But for a better human parallel, hasn't the very man who made this poem found nothing - no joy, no solace - in the scene he has created and finally, in this curt ending, also withdrawn himself in a sullen ignorance like that of the spider? In the poem, in short, hasn't Frost merely described himself?

Merely? Isn't it quite a trick, to be able to see oneself and one's most intimate vision of the world with such total detachment and remorseless honesty? It is something that Frost, like the rest of us, seldom, if ever, managed in life.

So how did it come about that he managed to do it in this poem? The answer to that question, I think, is (or can be) surprisingly simple: the poem is a sonnet. Its primary commitment is not to any previously discovered truth or to any intentional saying, but to form, to its manner of saying - whatever it is saying. As Frost himself remarked, he never even asked what a poem he was working on was going to mean; all he ever asked was, "How's it going?" This-and only this-commitment: the commitment to traditional form ("Is it going to be a good sonnet?") - can drop the barriers, the fears, the embarrassments, and make a deeper truth possible. It is like learning how to use your eyes in the darkness. You have to look away from what you hope (or fear) to see. I have commented on several fine effects in the poem which are made possible - or at least greatly enhanced-by its commitment to external form; but these are only incidental. Central is the commitment to being a sonnet, to join all the other sonnets and similar types of poem in English and the rest of European Literature: to invite comparison with them, to find its way essentially as they have found their way.

It is a central paradox of art and society that such self-discovery can only be accomplished by such subjugation of the self to tradition. We all know that a poet is a fellow who stands alone on a cliff, facing the tempestuous elements, the chaos that threatens to engulf us all: a Prometheus, a William Blake grasping the fires of Heaven, a Hölderlin off to Patmos. But I have just said that a poet is something else too. Dread word. Poets are joiners. Rotarians of the psyche! Whatever cliffs they may have been standing on, sooner or later they will sit down and write a poem. (Otherwiseand this is sometimes lost sight of - they themselves and where they have been standing will be of no consequence to us whatever. Such a person 
might then be what the Taoists in Ancient China called a Sage: one so wise as to have no need of thoughts, poems, wisdom even - thereby becoming invisible to his fellow men.) But if there is going to be a poem at all, it must be part of a social reality; it must be recognizably like the other poems that we know about: it must join them. It must submit to them, must be as they are.

To choose to write a poem in a particular verse form, as a sonnet, simply emphasizes this aspect of what always happens when a poet writes poetry. All poetry has a standard, a conventional element, lives, in fact, in an atmosphere of convention - breathes in it. No poet, not even a W. C. Williams, as we shall see, can escape this. Yet, far from stifling our individualities, this need to be conventional enables us to become the individuals we are. In order to be like all the other sonnets in the deepest way, the new sonnet must be original and unique as they are original and unique. They are all different from each other. This new member of the group, therefore, must also be different from all the others. In order to be truly like them, in short, it must be different from them.

In general, the only way to be free and original is to try to be conventional and controlled, and this, in general, is what all sonnets, all forms of art, tell us when we read them. It was through the discipline and conventions of speech that we left the world of beasts and gained our freedom as human beings; and it is through submission to the additional stricter discipline and conventions of the art that the poet gains his or her powers of wisdom and prophecy.

Let us now turn to William Carlos Williams. It has been said that his poems are so different in character from the customary "well-made" poems of the kind we have just been looking at that they cannot even be discussed in the same way. For example-

\section{THE RED WHEELBARROW}

so much depends

upon

a red wheel

barrow 
glazed with rain

water

beside the white

chickens

This simple declarative sentence, apparently innocent of any art or artifice, is so forthrightly inconsequential that it has seemed to many less like a poem in any usual sense than like someone thumbing his nose at poetry. Williams and his severest critics have been in agreement on this point. But it is an illusion. This is a poem like other poems and has an excellence in no way fundamentally different from the excellence that poems have always had. For one thing, it has denouement, as Frost, surreptitiously quoting Aristotle, says that poems ought to have. Or to use Aristotle's more familiar word, that we thought had been taken over by the soap operas, it has a plot. To see this, we may stop it at its midpoint, see what it says up to there, and then take note of how the second half veers off in a surprising new direction. I fancy I have heard someone saying that first half-some politician praising the cornball virtures of the Corn Belt. Our sentimental hero, the sturdy American small farmer, symbolized by that wheelbarrow - so much depends on that (him): our dinners, our daughters' purity, our nuclear bombs (which, like his bumper crops, we store in "silos"). This wheelbarrow is what Americans are unquestionably good at. We may all be going mad, but we eat well. And why is that? Ladies and gentlemen, it is because we don't take any nonsense. That wheelbarrow is a strictly utilitarian object. We only painted it red so it wouldn't rot too quickly and so Daddy would see it and not bruise his shin on it when he was staggering around hung over on Sunday morning.

But the second half of the poem changes all this. The whole thing blows up like a firecracker into a shower of images - for which that "red" in the first half was a preparation - a little fiery fuse. The wheelbarrow ceases to be something you use and becomes instead something you look at and contemplate. It becomes a thing of beauty. And this is what "so much depends / upon"- our ability to see the wheelbarrow, see the things of our world in this contemplative esthetic way.

Allow me to dwell on this point. To keep warm in England some years ago, my wife and I used kerosene-the British called them "paraffin"- 
heaters. We filled them from two paraffin cans, a tall red one and a squat beige one, which we filled at the grocer's or the ironmonger's or somewhere. One day I saw these two cans in the hall, and I thought: 'There are the paraffin cans. They are empty, and they have to be filled.' This was an insipid stupid thought that gave me no pleasure at all, and I felt uncomfortable. But then, as I went on looking at them, I suddenly thought: 'There is a tall red one and a squat beige one, and I don't even know what they are or what they are supposed to do.' (I didn't really think all this. It all happened in an instant, like a light coming on.) 'I only know what they are doing now, there in that dingy corner. They are a composition. They look good. They intrigue. They have a being, a life-yes, why not a life even? - of their own. And that is so much better. That is marvelous.' And I felt marvelous.

I think that's what this poem is about: the need to rediscover our innocence. (I hope that by using that word, I do not make so fleeting, so delicate, so important a thing sound pompous.) But there is an irony in the poem as well, lurking in its crucial phrase, the opening one, "so much depends." That has always sounded to me like someone talking at a cocktail party. "So much depends upon ..." "Oh really? What makes you think so?" Etc., etc. The vague, abstract quality. So much what? Try to imagine someone who actually used a wheelbarrow beginning a sentence like that! It's that lingering tone in this opening phrase which gives this poemthat in our first perception of it had seemed so didactically sure of itselfits feeling of wistfulness, its sense of a world which is, after all, lost. The poem trails off: there are no verbs in the second half; it is all modifier.

Of course, this poem has verse form. It consists of four little units, each beginning with a two beat phrase and ending in a two syllable word. "Rubbish!" cry the detractors, "If the thing had been printed as prose, no one would have had the slightest inkling of such a 'form.' How would you say this poem so that the audience heard that pattern or was aware of it in any sense at all?" The objection brings out something of the nature of verse form and how it functions. If the audience-the listeners-don't know about it, then they probably aren't going to perceive it, and then what's the point of it existing? - and, more deeply, in that case, does it exist?

"You see it," cry the defenders. "There it is on the page. And of course the 'audience' is not aware of its form! The audience you are talking about 
is the audience for old poems. The audience for this poem hasn't been created yet. This poem is going to create its own audience. Already has! $\mathrm{Me}$, for instance."

Again the detractors: "Nonsense, and more nonsense! Your 'poet' merely hit on that pattern by chance and pretends in the printing that it was intended. That's just too easy." As Frost said, "No one wants to watch a tennis game where there is no net, no base lines. Such hit-or-miss forms are a hoax."

And again the reply: "You've just said what's wonderful about the form: it is not imposed from without like your mechanical iambics; it arises spontaneously from within. And if it does so by chance, so much the better. 'The magic hand of chance' . .."

"Keats said that -in iambics."

"It's unconscious, organic. It is a form founded on the natural rhythms of speech."

I think both these speakers are missing the point. The poem's form lies, as we have seen, in the way its sentence swoops and swerves to the surprising and inevitable conclusion; and its true, audible versification has the same source. This may be what the defenders of free verse mean when they speak - as they never tire of doing-of "form founded on the natural rhythms of speech."

But Frost knew all about this too. As he put it in his essay, "The Figure a Poem Makes," "The possibilities for tune from the dramatic tones of meaning struck across the rigidity of a limited meter are endless." Both poets have essentially the same idea of form; and as time goes on, it may come to seem less important than it does today that Frost puts in the meter and Williams leaves it out. Frost's statement and Williams' practice stem directly, I think, from perhaps the most famous statement on prosody in English Literature. The "musical delight" of poetry, says Milton in his little preface to Paradise Lost, "consists only in apt Numbers [meter], fit quantity of Syllables, and the sense variously drawn out from one Verse into another." Frost's statement is a useful and illuminating variation on Milton's.

To see where Williams' position comes in almost as a matter of necessity, we have to steep ourselves in Paradise Lost, saying great stretches of it aloud, preferably from memory, in order to grasp the actual results of Milton's theory. One quickly realizes that one is not aware of "the sense vari- 
ously drawn out from one Verse into another" because the run-on lines are so constant that one is not aware of the line divisions. One is aware of the iambic pulse, of course, and one has, somehow, a general sense of the length of the line, but beyond that, one is aware only of "the sense variously drawn out," aware, that is, only of Milton's grandiose, magnifcently unfolding sentences without reference to specific line length. Frost's response to this situation is to forget about the line breaks and emphasize the "rigid meter," the iambic pulse, in order to preserve the contrapuntal effect that he and Milton both treasure. Confronted with a defect in the classical theory, he redefines the theory in order to preserve its viability.

But another response is also possible. The contrapuntal effect, after all, may not be essential. (Indeed, musical history in the West is punctuated with rebellions against counterpoint, usually under the banner of simplicity and naturalness and usually short-lived.) One may say that since the line endings have been lost to the hearer, classical theory is flawed and the pulse too is inessential and can be dispensed with. The essence of the verse, the essence of all verse, is the variously unfolding sentence. This, and only this, is true verse form.

To see how far these thoughts are from idle speculations, consider Williams at what is certainly his very best:

\section{THESE}

are the desolate, dark weeks when nature in its barrenness equals the stupidity of man.

The year plunges into night and the heart plunges

lower than night

to an empty, windswept place without sun, stars or moon but a peculiar light as of thought 
that spins a dark firewhirling upon itself until, in the cold, it kindles

to make a man aware of nothing that he knows, not loneliness itself-Not a ghost but

would be embraced-emptiness, despair-(They whine and whistle) among

the flashes and booms of war; houses of whose rooms the cold is greater than can be thought,

the people gone that we loved, the beds lying empty, the couches damp, the chairs unused-

Hide it away somewhere out of the mind, let it get roots and grow, unrelated to jealous

ears and eyes - for itself.

In this mine they come to dig-all. Is this the counterfoil to sweetest

music? The source of poetry that seeing the clock stopped, says, The clock has stopped

that ticked yesterday so well? and hears the sound of lakewater splashing - that is now stone. 
What marvelous, breathtaking, sinuous, constantly surprising sentences! This poem is Miltonic not only in manner-its technique of variously drawing out the sense on continuously new levels of abstraction - it is also Miltonic in matter. It is an updating, a variation on Milton's Hell. The "peculiar light as of thought/ that spins a dark fire" owes everything to Milton's "from those flames / No light, but rather darkness visible;" and the sense of falling through level after level that one gets in the second through the seventh tercets is an actualization of Satan's sensations in the great soliloquy at the beginning of Book IV:

Which way I fly is Hell; myself am Hell;

And in the lowest deep a lower deep

Still threat'ning to devour me opens wide,

To which the Hell I suffer seems a Heav'n.

The despair so brilliantly expressed in "These" is literary as well as personal. No poet ever wrote a more profoundly traditional poem than this.

Or take this familiar example of Williams' supposed disposition to paste casually observed little slices of life into his books:

\section{LOVE SONG}

Sweep the house clean, hang fresh curtains in the windows put on a new dress and come with me!

The elm is scattering its little loaves of sweet smells from a white sky!

Who shall hear of us in the time to come? Let him say there was a burst of fragrance from black branches. 
How long do we live with this charming piece before we realize that it is a flagrant recasting of "Come Live with Me and be my Love" - with a bit of Poundian Provençal and añother bit of Poundian Orientalism thrown in for the conclusion?

I do not mean to denigrate Williams' achievement. He is one of our finest poets - and poets have always imitated one another: it is one of their great strengths. But Williams should be seen for what he was: far more closely and narrowly tied to tradition-traditional subjects, traditional gestures, traditional attitudes - than Frost's wild oddness and egocentricity could ever have tolerated. "Range-Finding" is too intellectually shocking a poem to be in free verse. I feel the urge sometimes to quip that Williams' whole career was one long doomed struggle against his own gentility. Living in his suburb, practicing (with great nobility and dedication) his eminently respectable profession, having his rebellious little flings now and then, the poor man longed so to be outrageous and disreputable. And there all the while was Frost, writing his impeccable deadly stanzas, a dropout (but from two of our best colleges and a dropout, mind you, in classics)-who actually was disreputable. A failure as a farmer, responsible for a family of six, he spent the last pennies of his patrimony ... on what? A trip to England! We are beginning to realize, I think, that there have been few lives in America more deeply disturbing, more devestatingly questioning of its values, than Robert Frost's. Think of it: to have accepted, to have basked in the whole bit: the adulation of women's clubs, the four Pulitzer Prizes, the adoring attentions of a President whose main other amusement seems to have been sleeping with movie stars - to have gone through all this with an official biographer dutifully, worshipfully dogging your every step; and then after your death to have that same official biographer write about you in what could only have been cold fury and unmixed loathing. What an achievement!

Is it any wonder that Frost wrote in regular meters? Without them, he would clearly have gone mad. He himself said as much more than once. An instance? That little poem of his that we looked at first.

Williams was so much more decent and likable, so much more like the rest of us: silly sometimes, somewhat prone to sentimentality, but caring. He could write poems like "Tract" that are prosy, prolix, yet strangely affecting in their forthright concern for the values we live by. He is continually sermonizing like an overconfident bumpkin ready to rebuild our 
Broadways - and even our Wall Streets - from the ground up; and we forgive him because he is so obviously generous and well-meaning. A poet like this has a need to minimize the formal aspects of his art because he has little need of the heightened awareness that they produce. His primary urge is to speak for us all, and he can do that best by being as much like us as he can.

Williams was free, therefore, to devote the main part of his poetic activity to what is essentially a technical problem. Like a friendly and understanding schoolmaster, he laid out a grand project for us all and himself first grappled with its difficulties. Under his guidance America would produce a poetry completely free of the falseness of traditional rhetoric, a poetry without pretense, natural, unaffected, unartificial, that would show itself to be poetry only in its distinction of thought, phrase, and image. It is both relevant and beside the point to repeat Samuel Johnson's famous remark, that such Miltonic programs for freedom in verse can only result in severer forms of bondage. It is relevant because the prediction has come to pass and we are now harnessed to a poetic style that leaves only the merest hairline between prosaic dullness and mannered incoherence. (Lately it has even become fashionable for poets to achieve both effects at once.) And it is beside the point because so much fine poetry has come into being in the process.

So where does all this leave us? What conclusion is possible about rhyme and meter and their role in contemporary poetry? I remember hearing Allen Tate in the late ' 50 s, fuming about his former student, Robert Lowell: "You cain't like all the people at the same time that Cal says he likes. You just cain't like Robert Frost and William Carlos Williams at the same time." It seems to me that this is exactly what we have to learn to do, if we are going to pull ourselves together. Right brain, left brain: we have been talking about two sides of our being, both, I suspect, essential.

And indeed there appear to be very few poets as pure in their metrical devotions as Frost and Williams. Doubtless we are drawn to one side or the other by our own idiosyncrasies. (I have often thought, for example, that one's predilection for rhyme and meter- "numbers" as they were called in the seventeenth and eighteenth centuries - might be a reflection of one's attitude toward mathematics and that the ascendance of free verse in modern times might be a result of the current much-noted rift between the sciences and humanities. It also seems likely that our tendencies in this 
respect are influenced by our more-or-less conscious association of poetry with the other arts: that our rhymers are trying to make poetry musical and our free verse imagists prefer to think of it as painting.)

Yet there is hardly a poet who hasn't had it both ways at different times. Powerful forces catch us up and set us to oscillating between the extremes. On the one hand there is the felt artificiality of accentual-syllabic forms which, as I have remarked, appears to have been present from the beginning but which has become particularly intense in the twentieth century; on the other, there is the artist's drive to order and finality. A poem in "open form" can seem sloppy and unfinished. Yet this unfinished quality is certainly one of the attractions of open forms. They make a poem seem in process, like the sketches of a Leonardo or a Rubens that seem almost better because rougher and more alive than the finished work, which seems removed from life, unchanging, ho-hum. The rough sketch is still on its way, still exciting.

But isn't there something just a bit perverse and artificial about such preferences? Doesn't one have to be surrounded by museumfulls of tired old masterpieces, whose immediacy one has forgotten, in order to feel this way? After all, an unfinished work of art is meaningful only in relation to a finished one .... So maybe we ought to burn down the museums and start over. That too has been suggested. (The ancient Greeks and Romans were so wonderfully careless about their past that one has to believe they destroyed it almost deliberately. In Julius Caesar's day, for example, they burned down the Great Library at Alexandria, which contained a large portion of their literature and science in unique copies, as a side effect of a battle so minor that it could hardly be called much more than a street brawl.)

But if we burnt all our books of poetry and could somehow contrive to burn out of our brains all the poems that we remembered, then in our newfound lobotomized bliss, we would have to reinvent iambic, would we not?

So let us allow the libraries to stand, if possible, and in that spirit let us own up to the fact that a system of prosody is so useful that it amounts to a necessity. There is simply no way to prevent our sketches from turning, sooner or later, into finished works. As I have said, if we have any faith at all in poetry as a means for transcending our ordinary perceptions and inhibitions, we are inevitably going to turn to rhymes and meters to pick us 
up and carry us to destinations we dare not reach, nor even conceive, on our own.

It follows that in one important respect at least, the art of poetry in America for a generation or two has been, if not bent on destroying itself, at least neglectful of its survival. To answer our opening question: No, we have not done well to have turned away from formal verse so decisively that it has become virtually a lost skill, both in the composition and in the appreciation of our poetry.

But I would not have free verse outlawed either-as it seems to have been between, say, 1660 and 1860 (perhaps as a consequence of the rise of the novel). Open form is not quite as revolutionary as some would have us believe: it is firmly rooted in Shakespeare's prose and in the psalms and prophecies of the King James Bible. Let the two kinds thrive side-by-side, enlivening each other with their complementary energies: a precise and intricate formality that has the wonderful naturalness of one of Frost's great lyrics, and a careless freedom that somehow manages to be as memorable, as compelling, and as inevitable, word for word, as our great traditional verse - the freedom, for example, of those magical opening lines of The Cantos. 